\title{
Penggunaan Instagram Stories sebagai Media Promosi Kesehatan Mata
}

\author{
Hanna Nurul Husna \\ STIKes Bakti Tunas Husada
}

\author{
Itmam Milataka \\ STIKes Bakti Tunas Husada \\ Andika Khalifah Ardi \\ STIKes Bakti Tunas Husada
}

\author{
Nurul Zakiatul Jannah \\ Fitriani \\ STIKes Bakti Tunas Husada
}

\begin{abstract}
Instagram is one of the social media that is often used in Indonesia. The purpose of this community service activity is to provide information to the public about eye health by utilizing the Instagram "Stories" media. The target subjects are followers of the Instagram account @optometry.bth. The material that will be presented is unique facts about the eye, visual impairement, refractive errors, and eye diseases. The material is presented in the form of images, animations, and videos. Submission of material is also done directly or interspersed with interactions such as submitting responses in the form of questions, looking for pictures, and guessing songs. From the results of the activity, it is known that the largest number and average of views and discovery were obtained on the first day using video media. While the lowest was obtained on the seventh day with image media. The conclusion of this activity is that Instagram "Stories" can be used as a medium for promoting eye health. Followers of the @optometry.bth account feel the benefits of the information conveyed through this medium. However, the number of views and discovery of each story upload is largely determined by the number of followers, interesting content, and upload time
\end{abstract}

Keywords: Eye health; Health promotions; Instagram stories

\begin{abstract}
Abstrak
Instagram merupakan salah satu dari media sosial yang sering digunakan di Indonesia. Tujuan dari kegiatan pengabdian ini adalah untuk memberikan informasi kepada masyarakat mengenai kesehatan mata dengan memanfaatkan media Instagram Stories. Subjek sasaran kegiatan adalah pengikut akun Instagram @optometry.bth. Materi yang akan disampaikan adalah fakta unik tentang mata, keluhan penglihatan, kelainan refraksi, dan penyakit mata. Materi disajikan dalam bentuk gambar, animasi, dan video. Penyampaian materi pun dilakukan secara langsung ataupun diselingi dengan interaksi seperti pengajuan respon dalam bentuk pertanyaan, cari gambar, dan tebak lagu. Dari hasil kegiatan, diketahui bahwa jumlah dan rata-rata view dan discovery paling besar diperoleh di hari pertama dengan menggunakan media video. Sedangkan yang paling rendah diperoleh di hari ketujuh dengan media gambar. Kesimpulan dari kegiatan ini yakni Instagram Stories dapat digunakan sebagai media promosi kesehatan mata. Pengikut dari akun @optometry.bth merasakan kebermanfaatan informasi yang disampaikan melalui media ini. Meskipun demikian, banyaknya view dan discovery dari setiap unggahan stories sangat ditentukan oleh jumlah pengikut, konten yang menarik, serta waktu unggah.
\end{abstract}

Kata kunci: Instagram stories; Kesehatan mata; Promosi kesehatan

\section{Pendahuluan}

Penggunaan media sosial telah bekembang pesat di sepuluh tahun terakhir ini. Media sosial kerap digunakan mulai dari komunikasi dengan kerabat dan relasi hingga memperbarui berita dan gosip terkini [1]. Penggunaan internet yang sangat masif serta kemudahan dalam memiliki dan menggunakan smartphone diduga menjadi faktor pendorong meningkatnya pengguna media sosial di Indonesia. 
Dalam Datareportal [2], dinyatakan bahwa terdapat sekitar 202.6 juta pengguna internet dan 170 juta pengguna media sosial di Indonesia. Di Indonesia, YouTube merupakan media sosial yang paling sering digunakan, disusul oleh Whatsapp dan Instagram.

Penggunaan internet dan media sosial tidak akan hanya memberikan manfaat tapi juga memunculkan permasalahan lainnya. Permasalahan kesehatan yang sering disinggung dalam penggunaan media sosial adalah social anxiety [3] dan kesehatan mata [4]. [5] mengungkapkan bahwa rata-rata penggunaan media sosial di Indonesia setiap harinya adalah 3 jam 14 menit. Durasi penggunaan gadget yang terlalu lama akan berpengaruh terhadap mata lelah [6] dan tajam penglihatan [7].

Instagram merupakan sebuah media sosial yang membagikan foto dan video [8]. Instagram membuat interaksi antar jejaring pengguna yang saling berkaitan ataupun interaksi dalam cakupan yang lebih luas lagi [9]. Instagram bukan hanya sebagai satu satunya media sosial yang berkembang sangat pesat, tapi juga sebagai ruang sosial virtual dimana orang lebih suka menghabiskan waktunya disana; orang mengunjungi Instagram 45 persen lebih lama dari Facebook, dan 40 persen lebih lama dari Twitter. Beberapa penelitian telah dilakukan mengenai penggunaan Instagram sebagai media promosi kesehatan. [10] menggunakan video yang diunggah di post Instagram sebagai media promosi kesehatan tentang bahaya merokok. [9] menggunakan Instagram sebagai media untuk mendukung kegiatan menyusui. Prodi Optometri memiliki media sosial yaitu laman Instagram @optometry.bth. Laman tersebut memiliki interaksi yang baik dengan pengikut yang tersebar nasional dan internasional. Banyaknya pengikut di Instagram ini dapat dimanfaatkan sebagai subjek sasaran promosi kesehatan mata.

Tujuan dari kegiatan pengabdian ini adalah untuk memberikan informasi kepada masyarakat mengenai kesehatan mata dengan memanfaatkan media Instagram Stories. Stories di Instagram memungkinkan pengguna untuk mengunggah konten berupa foto, video pendek, dan siaran langsung yang bisa dilihat dalam jangka waktu 24 jam. Merujuk pada desain dan tampilan, berbeda dengan tampilan media sosial lainnya dimana pengguna harus scroll down untuk melihat konten, stories muncul secara langsung selama 15 detik. Masing-masing story bisa diikuti dengan story lainnya, dan pengguna dapat mengkontrol saat melihat story (lanjut, kembali, dll) [11]. Fitur dan tampilan yang berbeda pada Instagram Stories dibandingkan dengan media sosial lainnya sangat memungkinkan untuk menciptakan interaksi dengan orang-orang sehingga sangat cocok untuk digunakan sebagai media promosi kesehatan mata.

\section{Metode Pelaksanaan}

Kegiatan pengabdian masyarakat ini dilakukan secara online melalui Instagram Stories dari akun @optometry.bth. Kegiatan dilakukan civitas akademika Prodi Optometri yang terdiri dari dosen, asisten, dan mahasiswa.

Populasi dari kegiatan ini adalah pengguna Instagram. Sasaran kegiatan adalah pengikut Instagram @optometry.bth dan orang-orang yang berada dalam jangkauan Instagram melalui hashtag (\#), explore, stories, dan lain-lain. Saat kegiatan ini dilaksanakan, akun @optometry.bth memiliki pengikut sekitar 4.300 orang. Pengikut akun ini berada dalam rentang usia 13-65 tahun dengan pengikut terbesar berada di rentang usia $18-24$ tahun (40,8\%). Pengikut tersebar secara internasional dan nasional dengan lokasi Tasikmalaya, Indonesia dengan persentase yang paling besar.

Metode yang digunakan adalah kualitatif konten analisis dari Instagram Stories. Tim kegiatan menggunakan Instagram Stories sebagai media promosi kesehatan mata. Kegiatan yang pertama kali dilakukan adalah analisis responden. Analisis ini diperlukan untuk menyesuaikan penggunaan tata tulisan, bahasa, serta style penyampaian materi promosi. Setelah tahapan ini dilakukan, selanjutnya adalah tahap perumusan materi. Karena subjek kegiatan adalah masyarakat umum, maka materi promosi yang diberikan harus yang berkaitan dengan kejadian dan fenomena yang sering ditemukan dalam kegiatan sehari-hari. Materi yang akan disampaikan 
adalah fakta unik tentang mata, keluhan penglihatan, kelainan refraksi, dan penyakit mata. Bentuk kegiatan ini mirip dengan penyuluhan kesehatan mata, tapi dilaksanakan secara online tanpa terikat waktu. Tim kegiatan tidak melakukan evaluasi mengenai keefektifan media sebagai media promosi kesehatan mata. Tim kegiatan melakukan voting mengenai tanggapan viewer story mengenai kebermanfaatan informasi yang disampaikan.

\section{Hasil dan Pembahasan}

Kegiatan pengabdian masyarakat yang dilakukan adalah pembuatan media promosi kesehatan mata yang ditayangkan di Instagram Stories. Kegiatan ini dilaksanakan dari akhir Maret-Juli 2021 dalam rangka memperingati World Optometry Day 2021. Karena kondisi pandemi COVID-19 yang terjadi sekarang ini, kegiatan tidak bisa dilaksanakan secara langsung berinteraksi dengan masyarakat sebagaimana biasanya, maka media secara online digunakan untuk mengakomodir kegiatan ini.

Kegiatan pengabdian masyarakat ini dilaksanakan secara online. Sasaran kegiatannya adalah orang-orang yang menjadi pengikut dari akun @optometry.bth (sekitar 4.300 orang per bulan April 2021) serta orang-orang lainnya yang bisa dijangkau oleh Instagram. Pengikut terbesar akun ini berada dalam rentang usia 18-24 tahun (40,8\%). Bentuk kegiatan yang dilakukan adalah penanyangan informasi melalui Instagram Stories. Kegiatan ini dilakukan secara online, tidak ada pertemuan langsung, dan bisa diakses kapanpun dalam jangka waktu 24 jam penayangan stories. Tingkat ketersampaian media dilihat dari jumlah view masing-masing konten. Dua dosen, dua asisten, dan dua mahasiswa menjadi kontributor konten dan teknis pada kegiatan ini.

Tahapan persiapan yang dilakukan adalah penggalian informasi mengenai karakteristik subjek pengikut akun. Hal ini penting dilakukan karena memahami karakteristik subjek akan mempengaruhi bagaimana media promosi dibuat dan akan mempengaruhi penyerapan informasi yang disampaikan. Berdasarkan penelusuran, pengikut akun media sosial @optometry.bth paling banyak berada di rentang usia 18-34 tahun (40,6\%). Oleh karena itu, pembuatan media harus menyesuaikan dengan selera dan style pengikut yang kebanyakan merupakan golongan milenial.

Tahap selanjutnya adalah persiapan materi. Materi kesehatan mata yang disampaikan harus berhubungan dengan fenomena yang sering ditemukan masyarakat dalam kehidupan sehari-hari. Materi yang akan disampaikan dalam adalah fakta unik tentang mata, keluhan penglihatan, kelainan refraksi, penyakit mata, dan pemeriksaan mata. Di tahap ini mahasiswa dilibatkan. Mahasiswa -dengan bimbingan dosen- membuat poster ukuran 1:1 dan 3:1 (sesuai ukuran Instagram Post dan Stories). Beberapa materi hasil perkuliahan Klinik Optik 1 (1) (Surfacing Lens) dimasukkan menjadi materi promosi. Materi lainnya diperoleh dari penelusuran sumber pustaka dan internet. Hasil karya mahasiswa dievaluasi oleh tim sesuai dengan kriteria seperti pemilihan ukuran dan jenis font; serta penempatan tulisan dan gambar. Jika sudah sesuai, maka materi siap ditayangkan (posting).

Setelah materi dipersiapkan, tahapan selanjutnya adalah penentuan timeline pengunggahan media. Rentang waktu yang direncanakan cukup panjang yaitu dari akhir Maret hingga Juni 2021. Meskipun demikian, setiap minggunya tidak selalu dirancang untuk mengunggah materi. Hal ini berdasarkan pertimbangan kesibukan akademik dosen dan mahasiswa, serta kesiapan materi informasi. Pengkajian dan pendalaman materi secara komprehensif harus dilakukan untuk diperoleh materi yang baik dan benar.

Tahap selanjutnya adalah pengunggahan iklan. Setiap petugas masing-masing diberi tugas untuk mengunggah materi dalam bentuk stories di akun Instagram @optometry.bth. Terdapat beberapa tipe media yang diunggah. Ada yang berupa gambar, animasi (gambar bergerak), dan video. Contoh cuplikan konten disajikan pada Gambar 1 di bawah ini. 


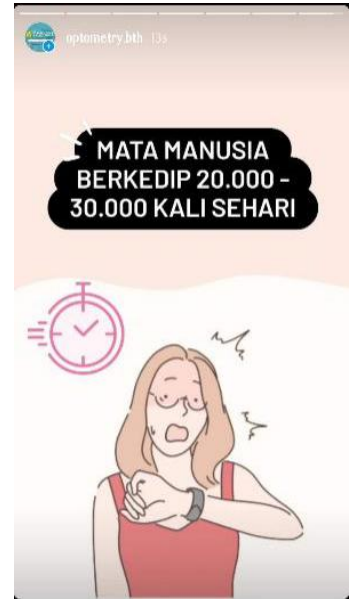

(a)
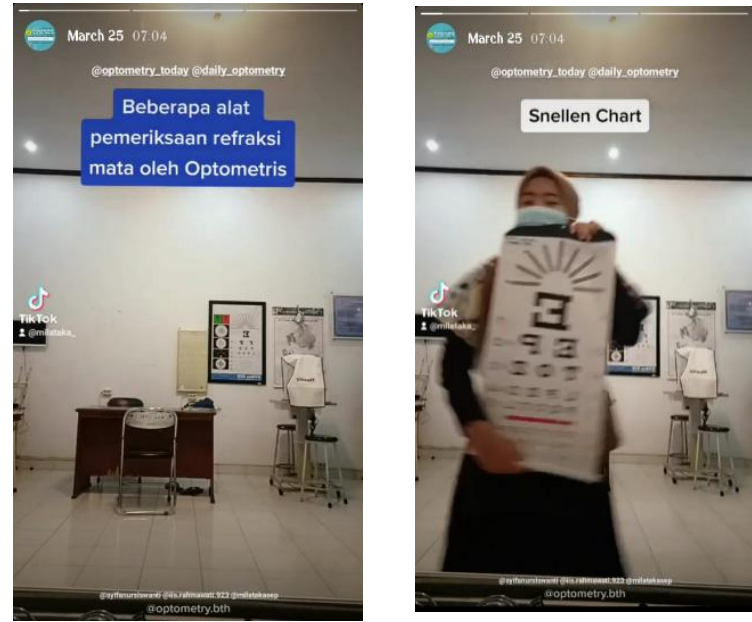

(c)
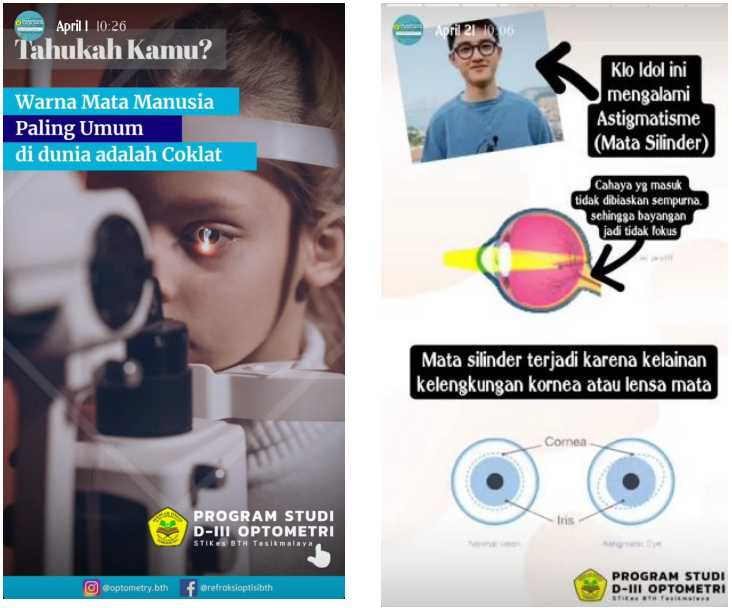

(b)
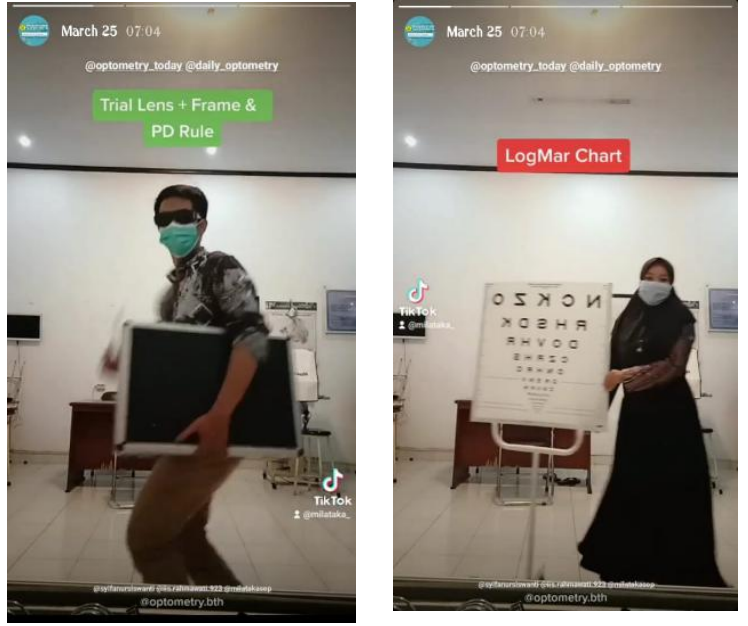

Gambar 1. Konten promosi kesehatan mata dalam bentuk gambar (a); animasi (b); dan video (c)

Gambar 1 menunjukkan beberapa cuplikan konten promosi kesehatan mata dalam bentuk gambar, animasi, dan video. Gambar 1a menunjukkan informasi fakta mengenai mata, begitupun dengan Gambar 1b. Perbedaannya gambar 1a disajikan dalam bentuk statis, dan gambar $1 \mathrm{~b}$ disajikan dalam bentuk animasi. Gambar statis yang dimaksud adalah berupa tampilan gambar dan/atau materi yang disertai dengan penjelasan materi tersebut. Sedangkan animasi yang ditampilkan berupa gambar materi dan penjelasan tapi disertai dengan beberapa stiker GIF bergerak yang diperoleh dari fitur Giphy serta lagu yang diperoleh dari aplikasi Storybeat. Gambar 1c menunjukkan alat pemeriksaan tajam penglihatan mata yang disajikan dalam bentuk video yang dibuat menggunakan aplikasi Tiktok.

Penyampaian media pun dilakukan secara langsung ataupun diselingi dengan interaksi seperti pengajuan respon dalam bentuk pertanyaan, cari gambar, dan tebak lagu. Perbedaan jenis media dimaksudkan sebagai variasi media. Tidak ada pertimbangan tertentu dalam pemilihan penyampaian media. Hal ini disesuaikan pada kemampuan tim. Beberapa variasi penggunaan media ditampilkan dalam Gambar 2. 

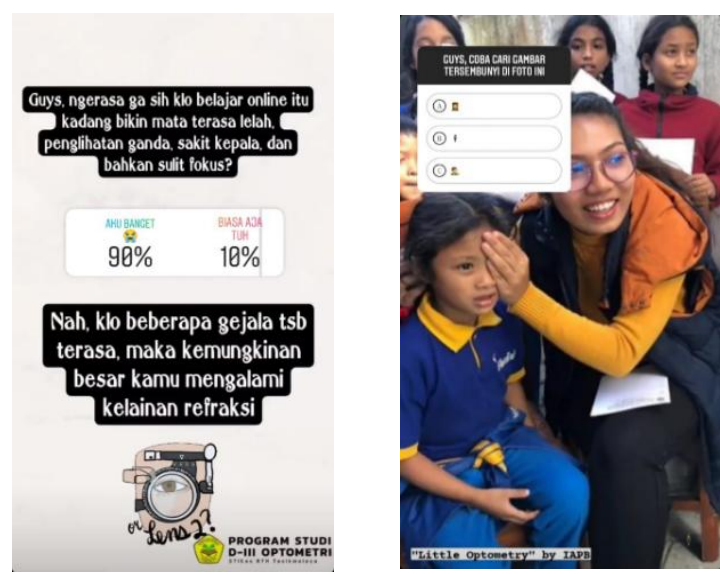

Gambar 2. Variasi penyampaian media menggunakan pertanyaan (kiri) dan permainan (kanan)

Dari setiap story yang ditayangkan Instagram "Stories", dapat dilihat insight mengenai view dan discovery dengan story tersebut. Discovery adalah ukuran yang menunjukkan seberapa banyak orang melihat konten dan dimana mereka menemukannya. Besaran-besaran ini tidak dihitung secara manual tapi berdasarkan perhitungan algoritma yang telah ditentukan Instagram. Tabel 1 di bawah ini menunjukkan jumlah interaction dan discovery dari Instagram stories yang ditanyangkan.

Tabel 1. Jumlah Interaction dan Discovery dari Instagram Stories

\begin{tabular}{crcrc}
\hline \multirow{2}{*}{ Hari ke } & \multicolumn{2}{c}{ View } & \multicolumn{2}{c}{ Discovery } \\
\cline { 2 - 5 } & Jumlah & Rata-rata & Jumlah & Rata-rata \\
\hline 1 (2 stories) & 569 & 285 & 571 & 286 \\
2 (7 stories) & 1.445 & 206 & 1.466 & 209 \\
3 (2 stories) & 339 & 170 & 342 & 171 \\
$4(1$ stories $)$ & 173 & 173 & 174 & 174 \\
$5(1$ stories $)$ & 128 & 128 & 137 & 137 \\
$6(2$ stories $)$ & 427 & 214 & 432 & 216 \\
$7(1$ stories $)$ & 126 & 126 & 130 & 130 \\
$8(1$ stories $)$ & 153 & 153 & 154 & 154 \\
$9(5$ stories $)$ & 1.365 & 273 & 1.403 & 281 \\
$10(7$ stories $)$ & 1.317 & 188 & 1.338 & 191 \\
$11(5$ stories $)$ & 738 & 148 & 750 & 150 \\
\hline
\end{tabular}

Berdasarkan Tabel 1, dapat dilihat bahwa jumlah dan rata-rata paling besar diperoleh di hari pertama penayangan. Di hari tersebut, informasi disampaikan melalui video mengenai alatalat pemeriksaan mata (Gambar 1.c). Jumlah dan rata-rata yang paling rendah diperoleh di hari ke-7 penayangan. Di hari tersebut, informasi disampaikan melalui animasi mengenai fakta kesehatan mata. Jumlah dan rata-rata view dan discovery di setiap hari penayangannya fluktuatif dan tidak menentu. Berdasarkan pengamatan dan evaluasi terdapat beberapa faktor yang menentukan jumlah viewer dan interaction yaitu jumlah pengikut, konten yang menarik, dan waktu unggah.

Keterbatasan akses internet dan media sosial di Indonesia yang belum menyeluruh menyebabkan informasi terbatas hanya pada orang-orang yang memiliki akun Instagram dan juga Facebook. Berdasarkan data analisis, bahwa orang-orang ini terkonsentrasi pada kaum 
milenial (18-34 tahun). Oleh karena itu, informasi melalui Instagram kurang bisa menjangkau orang-orang yang tidak memiliki media social. Selain itu, kegiatan ini hanya melibatkan unggahan story di media sosial maka jangkauan dari konten tersebut sangat tergantung dari jumlah pengikut dari akun media sosial tersebut. Akun media sosial Optometri dapat dikatakan baru dan belum memiliki jumlah pengikut yang banyak dibandingkan dengan akun public figure lainnya. Akan tetapi berdasarkan pengamatan, jumlah pengikut di setiap unggahannya terus meningkat. Hal ini berdampak pada peningkatan view dan interaksi di unggahan selanjutnya.

Konten yang menarik menjadi salah satu ukuran penyerapan informasi pada khalayak. Konten yang menarik dan unik cenderung lebih menarik perhatian dan informasi yang disampaikan lebih mudah untuk diresapi dan dipahami. Konten berhasil dibuat dalam bentuk video, gambar, animasi dan suara. Konten video yang unik mendapatkan view dan discovery yang paling baik dibandingkan bentuk media yang lain. Bentuk media berupa animasi dan suara pun memiliki respon yang lebih baik juga dibandingkan dengan gambar biasa. Hal ini menunjukkan bahwa bentuk media akan mempengaruhi kesan dari penyampaian informasi tersebut. Akan tetapi, permasalahan dalam pembuatan konten di kegiatan ini adalah keterbatasan managemen waktu dan keahlian dari masing-masing personel. Konten yang menarik membutuhkan kreativitas. Untuk beberapa orang kreativitas dalam membuat konten tidak bisa dilakukan secara serta merta, tapi membutuhkan observasi dan lingkungan yang mendukung.

Faktor lain yang mendukung dalam efektifitas penyampaian informasi iklan adalah waktu unggah. Story dan post akan lebih banyak mendapatkan view dan interaksi jika diunggah di waktu utama (prime time). Waktu-waktu yang dimaksud adalah pada sekitar pukul 9 pagi, 12 siang, dan 6 malam. Data-data ini diperoleh berdasarkan data insight yang diperoleh di akun Instagram.

Pada kegiatan pengabdian masyarakat ini, tidak dilakukan evaluasi secara formal mengenai keefektifan media sebagai media promosi kesehatan mata. Penulis melakukan voting mengenai tanggapan viewer story mengenai kebermanfaatan informasi yang disampaikan. Dan dari 100\% responden menganggap bahwa informasi yang disampaikan bermanfaat.

\section{Kesimpulan}

Instagram Stories dapat digunakan sebagai media promosi kesehatan mata. Penyampaian informasi melalui media ini cocok digunakan bagi golongan milenial yang memiliki media sosial. Pengikut dari akun @optometry.bth merasakan kebermanfaatan informasi yang disampaikan melalui media ini. Meskipun demikian, banyaknya view dan discovery dari setiap unggahan stories sangat ditentukan oleh jumlah pengikut, konten yang menarik, serta waktu unggah.

\section{Ucapan Terima Kasih}

Terima kasih kepada P3M STIKes Bakti Tunas Husada atas dukungannya sehingga kegiatan pengabdian masyarakat ini bisa terlaksana dengan baik.

\section{Daftar Pustaka}

[1] S. Edney, S. Bogomolova, J. Ryan, T. Olds, I. Sanders, and C. Maher, "Creating Engaging Health Promotion Campaigns on Social Media: Observations and Lessons From Fitbit and Garmin," J. Med. Internet Res., vol. 20, no. 12, p. e10911, Dec. 2018, doi: 10.2196/10911.

[2] S. Kemp, "DIGITAL 2021: INDONESIA," Data Reportal, 2021. https://datareportal.com/reports/digital-2021-indonesia (accessed Jul. 03, 2021).

[3] S. Jiang and A. Ngien, "The Effects of Instagram Use, Social Comparison, and Self-Esteem on Social Anxiety: A Survey Study in Singapore," Soc. Media Soc., vol. 6, no. 2, p. 205630512091248, Apr. 2020, doi: 10.1177/2056305120912488. 
[4] C. Maitra and J. Rowley, "Using a social media based intervention to enhance eye health awareness of members of a deprived community in India," Inf. Dev., p. 026666692110134, May 2021, doi: 10.1177/02666669211013450.

[5] H. Nurhayati, "Average time spent using online media in Indonesia in Q3 2020, by activity,” Statista, 2021. https://www.statista.com/statistics/803524/daily-time-spentusing-online-media-by-activity-indonesia/ (accessed Jul. 03, 2021).

[6] N. N. Rahmat, A. Munawir, and S. Bukhori, "Duration of Gadget Usage Affects Eye Fatigue in Students Aged 16-18 Years," Health Notions, vol. 1, no. 4, 2017, doi: 10.33846/HN.V1I4.69.

[7] T. Wahyuningrum and V. E. Prameswari, "THE RELATIONSHIP BETWEEN GADGET ADDICTION AND VISUAL ACUITY IN ELEMENTARY SCHOOL STUDENT OF MLIRIP II MOJOKERTO," Int. J. Nurs. Midwifery Sci., vol. 2, no. 3, 2018.

[8] NN, "Instagram," 2021. https://en.wikipedia.org/wiki/Instagram

[9] A. R. Marcon, M. Bieber, and M. B. Azad, "Protecting, promoting, and supporting breastfeeding on Instagram," Matern. Child. Nutr., vol. 15, no. 1, Jan. 2019, doi: 10.1111/mcn.12658.

[10] A. Wulantari and Y. Rahmayanti, "Gambaran Pengguna Media Sosial Facebook Dan Instagram Dalam Promosi Kesehatan Bahaya Merokok," KANDIDAT, vol. 1, no. 2, pp. 4755, 2019.

[11] D. Belanche, I. Cenjor, and A. Pérez-Rueda, "Instagram Stories versus Facebook Wall: an advertising effectiveness analysis,” Span. J. Mark. - ESIC, vol. 23, no. 1, pp. 69-94, May 2019, doi: 10.1108/SJME-09-2018-0042. 


\section{Afiliasi:}

Hanna Nurul Husna*, Itmam Milataka, Nurul Zakiatul Jannah Fitriani, Andika Khalifah Ardi Program Studi Optometri, STIKes Bakti Tunas Husada

Jl. Cilolohan No. 36, Kota Tasikmalaya

Email: hannanurulhusna@stikes-bth.ac.id* 